\title{
IN VITRO ANTIOXIDANT ACTIVITY AND PHYTOCHEMICAL SCREENING OF LEAF EXTRACTS OF GREWIA HETEROTRICHA MAST
}

\author{
B. USHA ${ }^{2}$, K. C. PUSHPALATHA 2 \\ ${ }^{1}$ Department of Biochemistry, Alva's College, Vidyagiri, Moodbidri, D. K. 574227, Karnataka, India, ${ }^{2}$ Department of Microbiology and \\ Biochemistry, Mangalore University, P. G. Centre, Chikka Aluvara, Kushalnagar, Kodagu, Karnataka, India \\ Email: usharao27@gmail.com
}

Received: 31 Jul 2016, Revised and Accepted: 06 Sep 2016

ABSTRACT

Objective: To investigate the presence of phytochemical components and to evaluate the in vitro antioxidant activity of pet. ether, chloroform, methanol and aqueous extracts of Grewia heterotricha mast leaves.

Methods: The leaves of Grewia heterotricha mast were dried and extracts were prepared using a pet. ether, chloroform, methanol by soxhlet extraction method. The aqueous extract was prepared using distilled water by cold extraction method. The preliminary phytochemical analysis was carried out on aqueous, methanol, chloroform and pet. either leaf extracts of the plant using standard qualitative procedures. The total phenolic content (TPC) was estimated using modified Folin-Ciocalteau method, tannin content by Folin-Denis method and total flavonoids by aluminum chloride method. In vitro, antioxidant activities were evaluated by 1,1-Diphenyl-2-picrylhydrazyl (DPPH) radical scavenging activity, $\mathrm{H}_{2} \mathrm{O}_{2}$ scavenging activity and FRAP assay.

Results: The preliminary phytochemical analysis revealed the presence of complex bioactive constituents like phenols, tannins, alkaloids, terpenoids, flavonoids, saponins, steroids, glycosides, coumarins, proteins and carbohydrates. Methanolic extract showed highest total phenolic content $(87.58 \pm 2.52 \mathrm{mg} \mathrm{CE} / \mathrm{g}$ ) than aqueous extract $(78.46 \pm 5.36 \mathrm{mg} \mathrm{CE} / \mathrm{g})$. Higher tannin content was found in the aqueous extract (148.0 $\pm 8.96 \mathrm{mg}$ $\mathrm{TAE} / \mathrm{g})$. Total flavonoids were highest in chloroform extract $(314.9 \pm 25.06 \mathrm{mg} \mathrm{QE} / \mathrm{g})$ followed by aqueous $(242.98 \pm 32.42 \mathrm{mg} \mathrm{QE} / \mathrm{g})$ and methanolic extract $(217.0 \pm 18.32 \mathrm{mg} \mathrm{QE} / \mathrm{g})$ and lowest in a pet. ether extract $(188.86 \pm 23.35 \mathrm{mg}$ QE/g). The methanolic extract had shown very significant DPPH radical scavenging activity $\left(\mathrm{IC}_{50} 98.95 \mu \mathrm{g} / \mathrm{ml}\right.$ ) and $\mathrm{H}_{2} \mathrm{O}_{2}$ scavenging activity $\left(\mathrm{IC}_{50} 110.1 \mu \mathrm{g} / \mathrm{ml}\right)$ compared to the standard ascorbic acid. Higher reducing ability was observed in methanol extract $(131.8 \pm 11.67 \mathrm{mg} \mathrm{AE} / \mathrm{g})$.

Conclusion: The results obtained reveal that the leaves of Grewia heterotricha mast have potent antioxidant property. The observed activity may be associated with bioactive components like phenolics, flavonoids present in the leaf extracts and could have greater importance as therapeutic agents in oxidative stress-related degenerative diseases. Further studies are needed in order to purify bioactive compounds responsible for the antioxidant property.

Keywords: Grewia hetertricha mast, Antioxidant activity, Flavonoids, Phenolics, DPPH, Reducing power

(C) 2016 The Authors. Published by Innovare Academic Sciences Pvt Ltd. This is an open access article under the CC BY license (http://creativecommons.org/licenses/by/4.0/) DOI: http://dx.doi.org/10.22159/ijcpr.2016v8i4.15282

\section{INTRODUCTION}

A number of plants have been used in traditional medicine over many years. These medicinal plants have been considered as sources for new drugs to treat numerous diseases. Therapeutic properties of medicinal plants are due to the presence of a wide variety of bioactive components in them. The most important bioactive components are phenolic compounds, flavonoids, alkaloids, and tannins. These phytochemicals are secondary metabolites synthesized by the plants $[1,2]$.

The secondary metabolites like flavonoids and phenolic compounds are considered as strong antioxidants which have the ability to scavenge free radicals, inhibit the activity of lipoxygenase and prevent tissue damage [3-5]. Natural antioxidants can reduce the risks of various oxidative stress related diseases such as cancer, neurodegenerative disorders, heart diseases and inflammation [6-8].

Grewia heterotricha mast belongs to the family Malvaceae, is a scandent shrub common in forests and along hedges in India. It is widely used as folk medicine in wound healing, fever, bronchitis, and to cure some skin and intestinal infections [9]. The pharmacological properties of this plant have not yet been evaluated. Hence, the present study was undertaken to identify the bioactive components and to evaluate antioxidant activity of leaves of Grewia heterotricha mast by in vitro methods.

\section{MATERIALS AND METHODS}

\section{Collection of plant material}

Grewia heterotricha mast plants were collected from Udupi, during monsoon and post-monsoon seasons. The plant was authenticated by Dr. K. Gopalakrishna Bhat, Botanist, Udupi. A voucher specimen $(20 / 11 / 2013)$ has been kept in our laboratory for future reference. The leaves were washed, shade dried and finely powdered and stored in air-tight container.

\section{Preparation of extract}

The powdered leaves $(75 \mathrm{~g})$ were extracted successively with $350 \mathrm{ml}$ each of petroleum ether $\left(40-60^{\circ} \mathrm{C}\right)$, chloroform, methanol using Soxhlet extractor for $24 \mathrm{hr}$. The extracts were concentrated by evaporation using rotary vacuum evaporator to obtain dark viscous semi-solid. Similarly, water extract was also prepared by mixing leaf powder in distilled water and stirred continuously using magnetic stirrer for $48 \mathrm{hr}$. The mixture was filtered and the filtrate was then concentrated. All the extracts were stored in a refrigerator and were used for further study.

\section{Phytochemical screening}

The leaf extracts were tested for the presence of bioactive compounds like flavonoids, terpenoids, alkaloids, glycosides, tannins, phenolics, saponins carbohydrates and proteins by using standard methods [10-12].

\section{Quantitative analysis of antioxidant component}

Determination of total phenolic content

The total phenolic content was estimated using the modified FolinCiocalteu method [13]. $0.5 \mathrm{ml}$ of extract and $0.5 \mathrm{ml}$ Folin-Ciocalteu's reagent was mixed and the mixture was incubated at room

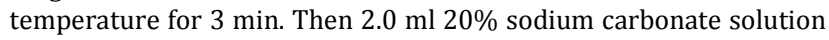


was added and further incubated in boiling water bath for $1 \mathrm{~min}$ and the absorbance was measured at $650 \mathrm{~nm}$. Catechol was used as a standard. Total phenol values are expressed in terms of catechol equivalent (mg CE/g of dry extract) [table 2].

\section{Determination of total flavonoids}

The total flavonoid content was determined by aluminum chloride method [14]. Extract solution ( $400 \mu \mathrm{g} / \mathrm{ml})$ of plant extract was added to $4 \mathrm{ml}$ of distilled water. Sodium nitrite solution $(0.3 \mathrm{ml}, 5 \%)$ was then added to the mixture followed by incubation for $5 \mathrm{~min}$ after which $0.3 \mathrm{ml}$ of $10 \%$ aluminum chloride was added. The mixture was allowed to stand for $6 \mathrm{~min}$ at room temperature before $2 \mathrm{ml}$ of $1 \mathrm{M}$ sodium hydroxide was finally added and the mixture diluted to $10 \mathrm{ml}$ with distilled water. The absorbance of the reaction mixture was measured at $510 \mathrm{~nm}$ with a UV/VIS spectrophotometer immediately. Quercetin was used as the standard for the calibration curve. Total flavonoids were expressed as mg quercetin equivalent (mg QE/g dry weight) [table 3].

\section{Determination of tannin content}

The tannin content was determined by Folin-Denis method $[13,15]$. $0.1 \mathrm{ml}$ of the sample extract was added with $7.5 \mathrm{ml}$ of distilled water and adds $0.5 \mathrm{ml}$ of Folin-Denis reagent, $1 \mathrm{ml}$ of $35 \%$ sodium carbonate solution and dilute to $1 \mathrm{ml}$ of distilled water. The mixture was shaken well, kept at room temperature for $30 \mathrm{~min}$ and absorbance was measured at $700 \mathrm{~nm}$. Blank was prepared with water instead of the sample. Tannic acid was used as a standard. The results of tannins are expressed in terms of tannic acid equivalent (mg TAE/g of dry extract) [table 4].

\section{In vitro antioxidant activity}

\section{DPPH radical scavenging activity}

DPPH radical scavenging activity was measured according to the method of Chu et al. [16] and Barku et al. [17]. An aliquot of $2 \mathrm{ml}$ of $0.004 \%$ DPPH solution in methanol and $1 \mathrm{ml}$ of plant extract in methanol at various concentrations $(100,200,300,400$ and $500 \mu \mathrm{g})$ were mixed and incubated at $25^{\circ} \mathrm{C}$ for $30 \mathrm{~min}$. and the absorbance of the test mixture was read at $517 \mathrm{~nm}$ using a spectrophotometer against a DPPH control containing only $1 \mathrm{ml}$ of methanol in place of the extract. Ascorbic acid was used as a standard. Percent inhibition was calculated using the following expression:

$$
\left.\% \text { Inhibition }=\left(A_{0}-A_{1}\right) / A_{0}\right) \times 100
$$

Where $A_{0}$ and $A_{1}$ stand for absorbance of the blank and absorbance of tested extract solution respectively

\section{Reducing power assay}

The reducing power assay of leaf extracts was determined by the method described by Oyaizu [18]. $2.5 \mathrm{ml}$ of $0.2 \mathrm{M}$ phosphate buffer (pH 6.6) and $2.5 \mathrm{ml}$ of $\mathrm{K}_{3} \mathrm{Fe}(\mathrm{CN})_{6}(1 \% \mathrm{w} / \mathrm{v})$ were added to $1.0 \mathrm{ml}$ of extract $(500 \mu \mathrm{g} / \mathrm{ml})$. The resulting mixture was incubated at $50{ }^{\circ} \mathrm{C}$ for $20 \mathrm{~min}$, followed by the addition of $2.5 \mathrm{ml}$ of Trichloroacetic acid $(10 \% \mathrm{w} / \mathrm{v})$. The mixture was centrifuged at $3000 \mathrm{rpm}$ for $10 \mathrm{~min}$. The upper layer of the solution $(2.5 \mathrm{ml})$ was collected and mixed with distilled water $(2.5 \mathrm{ml})$ and $0.5 \mathrm{ml}$ of $\mathrm{FeCl}_{3}(0.1 \%, \mathrm{w} / \mathrm{v})$. The absorbance was then measured at $700 \mathrm{~nm}$ against the blank sample. Ascorbic acid was used as a standard. Increased absorbance of the reaction mixture indicates an increase in reducing power.

\section{Hydrogen peroxide scavenging activity}

The ability of leaf extracts to scavenge hydrogen peroxide was determined by the method of Avani Patel et al. [14] and Gupta et. al [19] with minor modifications. $1.0 \mathrm{ml}$ of extract $(100-500 \mu \mathrm{g} / \mathrm{ml})$ was added to $2.0 \mathrm{ml}$ of $40 \mathrm{mmol}$ hydrogen peroxide solution prepared in $40 \mathrm{mmol}$ phosphate buffer ( $\mathrm{pH} 7.4)$. The absorbance was read at $230 \mathrm{~nm}$ after $10 \mathrm{~min}$. Ascorbic acid was taken as standard. The percentage inhibition was calculated.

$$
\left.\% \text { Inhibition }=\left(\mathrm{A}_{0}-\mathrm{A}_{1}\right) / \mathrm{A}_{0}\right) \times 100
$$

Where $A_{0}$ and $A_{1}$ stand for absorbance of the blank and absorbance of tested extract solution respectively

\section{RESULTS}

\section{Phytochemical Screening}

The present study was carried out in leaf extracts of Grewia heterotricha mast revealed the presence of different bioactive components. Terpenoids, flavonoids, saponins, steroids, glycosides, coumarins and carbohydrates were present in all extracts whereas phenols, tannins and proteins were present in methanol and aqueous extracts. Alkaloids were present only in a pet. ether and aqueous extract. The results are presented in table 1.

\begin{tabular}{|c|c|c|c|c|}
\hline Phytochemicals & Petroleum ether leaf extract & Chloroform leaf extract & Methanol leaf extract & Aqueous leaf extract \\
\hline Alkaloids & + & - & - & + \\
\hline Flavonoids & + & + & + & + \\
\hline Di-terpenoids & + & + & + & + \\
\hline Tri-terpenoids & + & + & + & + \\
\hline Saponins & + & + & + & + \\
\hline Tannins & - & - & + & + \\
\hline Glycosides/Steroids & + & + & + & + \\
\hline Phenols & - & - & + & + \\
\hline Anthocyanins & - & - & - & - \\
\hline Coumarins & + & + & + & + \\
\hline Carbohydrates & + & + & + & + \\
\hline Proteins & - & - & + & + \\
\hline
\end{tabular}

Table 1: Phytoconstituents in different leaf extracts of Grewia heterotricha mast

+represents compound present,-represents compound absent.

\section{Determination of total phenolic content}

The total phenolic content of the extracts was measured by using Folin-Ciocalteu reagent and results were expressed in terms of catechol equivalent (the standard curve equation $\mathrm{y}=0.02 \mathrm{x}-0.002$, $\mathrm{R}^{2}=0.9978$, fig. 1) shown in table 2. Methanolic extract of Grewia heterotricha leaves showed good phenolic content $(87.58 \pm 2.52 \mathrm{mg}$ $\mathrm{CE} / \mathrm{g}$ ) than aqueous extract (78.46 $\pm 5.36 \mathrm{mg} \mathrm{CE} / \mathrm{g})$.

\section{Determination of total flavonoid content}

The total flavonoid content of the extracts in terms of quercetin equivalent (the standard curve equation $y=0.0009 x+0.003$, $\mathrm{R}^{2}=0.998$, fig. 2 ) were shown in table 3 . The results revealed that the chloroform extract of Grewia heterotricha showed higher total flavonoid content $(314.9 \pm 25.06 \mathrm{mg} \mathrm{QE} / \mathrm{g})$ followed by aqueous (242.98 $\pm 32.42 \mathrm{mg} \mathrm{QE} / \mathrm{g})$ and methanolic extract $(217.0 \pm 18.32 \mathrm{mg}$ $\mathrm{QE} / \mathrm{g}$ ). Pet. Ether fraction had the lowest total flavonoid content (188.86 $\pm 23.35 \mathrm{mg} \mathrm{QE} / \mathrm{g})$.

Table 2: Total phenolic content in the leaf extracts of Grewia heterotricha mast

\begin{tabular}{ll}
\hline Extracts & mg Catechol/g dry extract \\
\hline Methanol & $87.58 \pm 2.52$ \\
Aqueous & $78.46 \pm 5.36$ \\
\hline
\end{tabular}

Each value represents mean \pm SD $(n=3)$. 


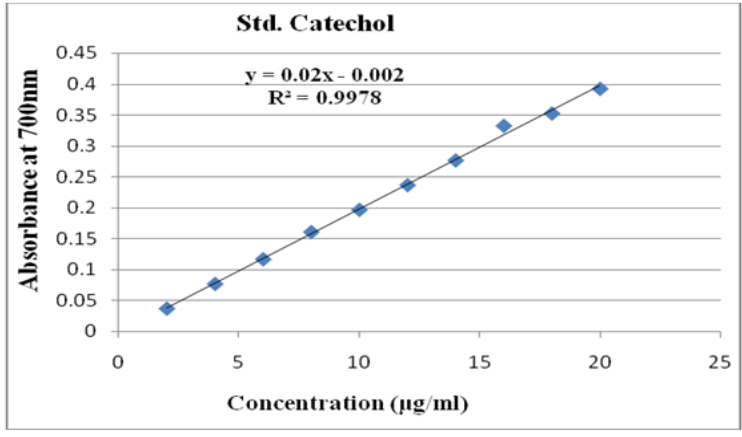

Fig. 1: Standard calibration curve for total phenolic content

Table 3: The total flavonoid content present in the leaf extracts of Grewia heterotricha mast

\begin{tabular}{ll}
\hline Extracts & mg quercetin/g dry extract \\
\hline Pet. ether & $188.86 \pm 23.35$ \\
Chloroform & $314.9 \pm 25.06$ \\
Methanol & $217.0 \pm 18.32$ \\
Aqueous & $242.98 \pm 32.42$ \\
\hline
\end{tabular}

Each value represents mean $\pm S D(n=3)$.

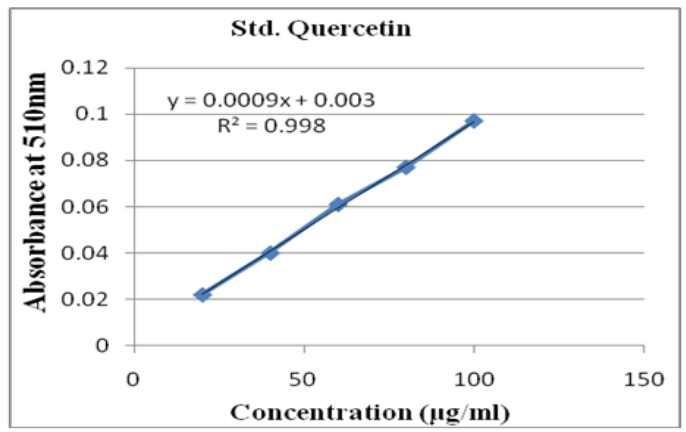

Fig. 2: Standard calibration curve for total flavonoid content

\section{Determination of tannin content}

The tannin content of the extracts was expressed as tannic acid equivalent/g of the dry extract (the standard curve equation $y=0.006 x+0.004, R^{2}=0.995$, fig. 3 ) were shown in table 4 . The results revealed that the aqueous extract of Grewia heterotricha have higher tannin content $(148.0 \pm 8.96 \mathrm{mg} \mathrm{TAE} / \mathrm{g})$ than methanolic extract (130.7 $\pm 8.05 \mathrm{mg} \mathrm{TAE} / \mathrm{g})$.

Table 4: The tannin content present in the leaf extracts of Grewia heterotricha

\begin{tabular}{ll}
\hline Extracts & mg tannic acid/g dry extract \\
\hline Methanol & $130.7 \pm 8.05$ \\
Aqueous & $148.0 \pm 8.96$ \\
\hline
\end{tabular}

Each value represents mean $\pm S D(n=3)$.

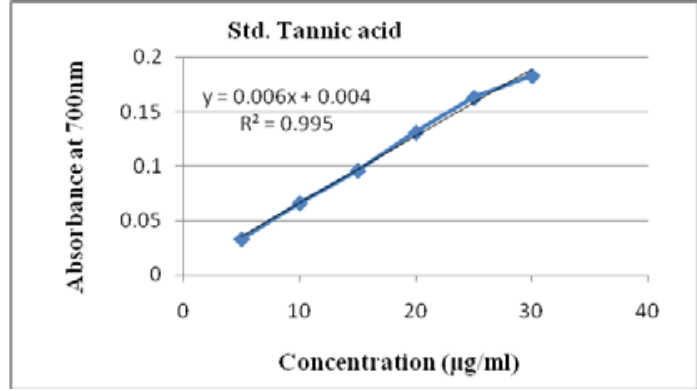

Fig. 3: Standard calibration curve for tannin content

\section{In vitro antioxidant activity}

\section{DPPH radical scavenging activity}

The antioxidant activity of different leaf extracts of the plant was investigated by DPPH radical scavenging assay using ascorbic acid as a standard. The results were summarized in table 5. The methanolic extract showed maximum free radical scavenging activity $\left(\mathrm{IC}_{50} 98.95\right.$ $\mu \mathrm{g} / \mathrm{ml}$ ) which was significantly comparable with free radical scavenging activity of ascorbic acid (IC $5013.44 \mu \mathrm{g} / \mathrm{ml}$ ).

Table 5: DPPH scavenging activity of the extracts

\begin{tabular}{|c|c|c|c|c|c|}
\hline \multirow[t]{2}{*}{ Concentration $(\mu \mathrm{g} / \mathrm{ml})$} & \multicolumn{5}{|c|}{ Extracts \% inhibition } \\
\hline & Pet. ether & Chloroform & Methanol & Aqueous & Ascorbic acid \\
\hline 100 & 9.3 & 10.8 & 52.6 & 19.2 & 82.97 \\
\hline 200 & 18.61 & 30.05 & 71.74 & 31.11 & 85.95 \\
\hline 300 & 25.97 & 39.48 & 85.39 & 38.50 & 89.09 \\
\hline 400 & 32.46 & 41.6 & 93.80 & 43.55 & 93.16 \\
\hline 500 & 40.25 & 43.41 & 94.60 & 49.8 & 95.72 \\
\hline $\mathrm{IC}_{50}(\mu \mathrm{g} / \mathrm{ml})$ & 631.5 & 525.9 & 98.95 & 508.3 & 13.44 \\
\hline
\end{tabular}

Vaues are mean $\pm S D(n=3)$.

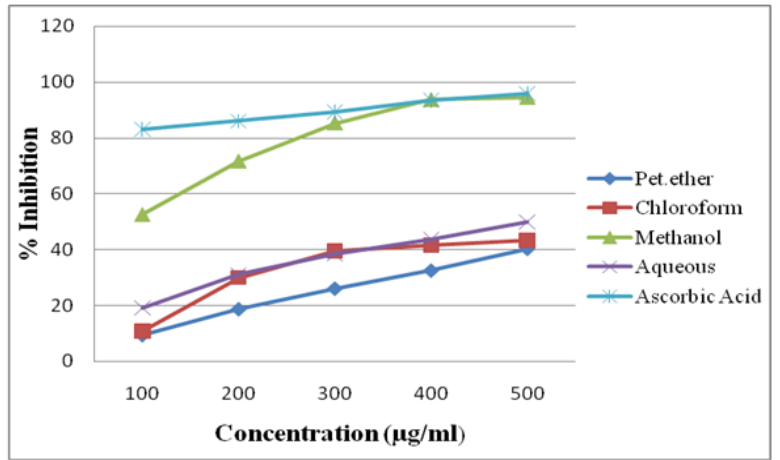

Fig. 4: DPPH scavenging activity of the leaf extracts of Grewia heterotricha mast

\section{Reducing power assay}

The results of reducing power assay are provided in table 5 . Absorbance is increased with increasing the concentration of the extracts. All the extracts showed potent reducing power ability. Among all the extracts tested, methanolic extract showed highest reducing ability $(131.8 \pm 11.67)$.

Table 6: Reducing power assay of the leaf extracts of Grewia heterotricha mast

\begin{tabular}{ll}
\hline Leaf extracts & mg ascorbic acid/g dry extract \\
\hline Aqueous & $73.0 \pm 4.47$ \\
Methanol & $131.8 \pm 11.67$ \\
Chloroform & $69.66 \pm 11.56$ \\
Pet. ether & $51.7 \pm 5.19$ \\
\hline \multicolumn{2}{l}{ Values are mean \pm SD $(\mathrm{n}=3)}$.
\end{tabular}




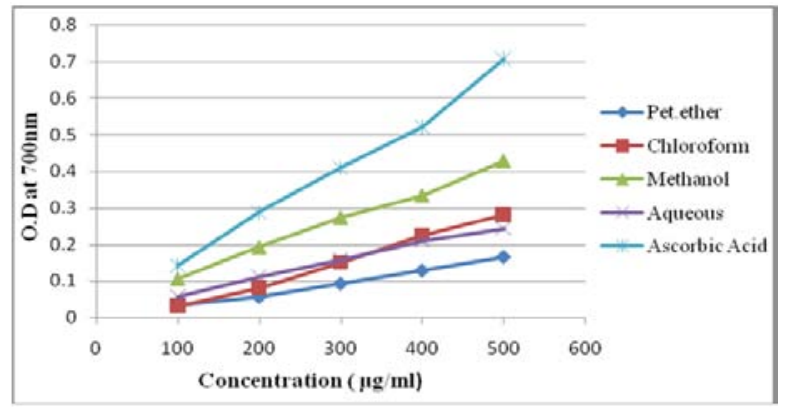

Fig. 5: Reducing power assay of the leaf extracts of Grewia heterotricha mast

\section{Hydrogen peroxide scavenging activity}

Scavenging of hydrogen peroxide by various extracts of the leaf was found to be concentration dependent. Maximum inhibition was shown by methanolic extract $\left(\mathrm{IC}_{50} 110.1 \mu \mathrm{g} / \mathrm{ml}\right.$ ) followed by chloroform (IC $50403.8 \mu \mathrm{g} / \mathrm{ml}$ ) and aqueous (IC $50685.6 \mu \mathrm{g} / \mathrm{ml})$ extracts (table 7 and fig. 6). Least scavenging activity was observed in a pet. ether extract $\left(\mathrm{IC}_{50} 403.8 \mu \mathrm{g} / \mathrm{ml}\right)$.

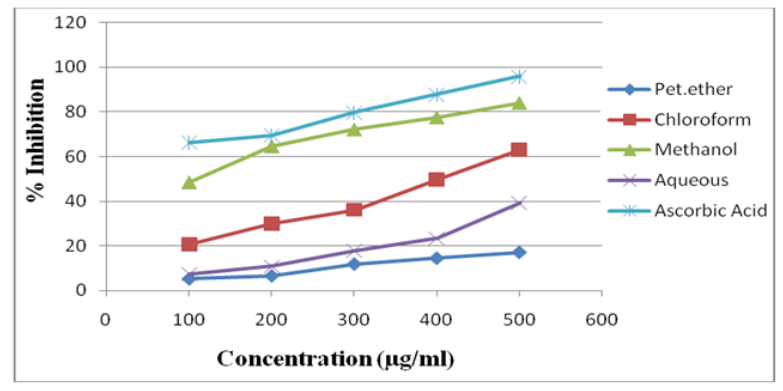

Fig. 6: Hydrogen peroxide scavenging activity of the leaf extracts of Grewia heterotricha mast

Table 7: Hydrogen peroxide scavenging activity of the leaf extracts Grewia heterotricha mast

\begin{tabular}{|c|c|c|c|c|c|}
\hline \multirow[t]{2}{*}{ Concentration $(\mu \mathrm{g} / \mathrm{ml})$} & \multicolumn{5}{|c|}{ Extracts \% inhibition } \\
\hline & Pet. ether & Chloroform & Methanol & Aqueous & Ascorbic acid \\
\hline 100 & 5.26 & 20.61 & 48.38 & 7.14 & 66.21 \\
\hline 200 & 6.57 & 29.89 & 64.51 & 10.71 & 69.59 \\
\hline 300 & 11.84 & 36.08 & 72.04 & 17.85 & 79.72 \\
\hline 400 & 14.47 & 49.48 & 77.41 & 23.21 & 87.83 \\
\hline 500 & 17.10 & 62.88 & 83.87 & 39.28 & 95.94 \\
\hline $\mathrm{IC}_{50}(\mu \mathrm{g} / \mathrm{ml})$ & 1531 & 403.8 & 110.1 & 685.6 & 57.96 \\
\hline
\end{tabular}

Vaues are mean $\pm \operatorname{SD}(n=3)$.

\section{DISCUSSION}

Secondary metabolites derived from plants are responsible for diverse pharmacological properties [20]. The antioxidant property of many plants is due to the presence of secondary metabolites such as phenolic compounds, flavonoids, tannins. Antioxidants play an important role in scavenging free radicals and provide protection against degenerative diseases [21,24]. It has been reported that the phenolic compounds present in plants possess antioxidant activity due to the presence of hydroxyl groups and they can act as potent hydrogen donors $[22,25]$. Flavonoids are the most diverse and widespread secondary metabolites involved in thrombosis, atherogenesis and carcinogenesis. It has been reported that pharmacological effects of flavonoids are correlating with their antioxidant activity. Flavonoids contain phenol groups and these are potent antioxidants. Tannins are abundant in plants and are used as astringents and also important in cancer treatment [23, 26-28]. These natural bioactive components are useful therapeutic agents in various degenerative diseases.

In the present study, preliminary phytochemical screening of different leaf extracts of grewia heterotricha mast showed the presence of steroids, alkaloids, tannins, diterpenoids, triterpenoids, saponins and phenolic compounds. All the four-leaf extracts of Grewia hetertricha were analyzed for total phenolic content, flavonoids and tannin content as well as for antioxidant activity by DPPH assay, reducing power assay and $\mathrm{H}_{2} \mathrm{O}_{2}$ scavenging activity. Results obtained for the above studies indicated maximum antioxidant activity in the methanolic extract of Grewia hetertricha which was significantly comparable with that of standard ascorbic acid. The methanol extract also exhibited the highest total phenolic content which can be positively correlated with its DPPH free radical scavenging activity.

The results suggested that all the four extracts of Grewia heterotricha have reducing property. Higher phenolic content in methanol extract might be responsible for maximum reducing ability. In the present study, the methanol and chloroform extracts exhibited highest $\mathrm{H}_{2} \mathrm{O}_{2}$ scavenging activity suggests that polyphenols, as well as flavonoids, may be responsible for antioxidant activity.

\section{CONCLUSION}

In conclusion, the present study revealed the presence of various bioactive components in the leaf extracts of Grewia heterotricha mast The plant leaves possess good phenolic content, total flavonoids and tannin content, in addition to other phytochemical components. The data obtained in the present study show that the leaf extracts have powerful antioxidant activity. The presence of phenolics, tannins and flavonoids may be responsible for this activity. Hence may be used for wound healing and in oxidative stress related diseases. Further studies are necessary to find the exact bioactive component involved in antioxidant activity.

\section{CONFLICT OF INTERESTS}

Declare none

\section{REFERENCES}

1. Oke JM, Hamburger MO. Screening of some Nigerian medicinal plants for antioxidant activity using 2,2 Diphenylpicrylhydrazyl radical. Afr J Biomed Res 2002;5:77-9.

2. Sofowora AO. Medicinal plants and traditional medicine in Africa. 2nd ed. University of Ife Press; 1993. p. 320.

3. Huang R, Mendis E, Kim SK. Factors affecting the free radical scavenging behavior of chitosan sulfate. Int J Biol Macromol 2005;36:120-7.

4. Halliwell B. Free radicals, reactive oxygen species and human disease: a critical evaluation with special reference to atherosclerosis. Br J Exp Pathol 1989;70:737-57.

5. Maria Doinița Bors, Sonia Socaci, Maria Tofana, Vlad Muresan, Ana Viorica Pop, Melinda Nagy, et al. Determination of total phenolics, flavonoids and antioxidant capacity of methanolic extracts of some brassica seeds. Bulletin UASVM Food Science and Technology 2014;71:205-6. 
6. Aruoma OI. Free radicals, oxidative stress and antioxidants in human health and disease. J Am Oil Chem Soc 1998;75:199-212.

7. Pietta PG. Flavonoids as antioxidants. J Nat Prod 2000; 63:1035-42.

8. Lewis DA. In: Anti-inflammatory drugs from plants and marine sources. Basel: Bikhauser Verlag; 1989.

9. Gopala Krishna Bhat K. Flora of Udupi; 2003. p. 76-7.

10. Nidhi Sharma, Vidya patni in vivo and in vitro qualitative phytochemical screening of Grewia species. Int J Biol Pharm Res 2013;4:634-9.

11. Thamaraiselvi, Lalitha $P$, Jayanthi P. Preliminary studies on phytochemicals and antimicrobial activity of solvent extracts of Eichhornia crassipes (Mart.) Solms. Asian J Plant Sci Res 2012;2:115-22.

12. Seema Firdouse, Parwez Alam. Phytochemical investigation of an extract of Amorphophallus campanulatus tubers. Int J Phytomed 2011;3:32-5.

13. Sadasivam S, Manickam A. Biochemical methods. $3^{\text {rd }}$ ed. New Dehli: New Age International Publishers; 2008.

14. Avani Patel, Amit Patel, Amit Patel, Patel NM. Estimation of Flavonoid, polyphenolic content and in vitro antioxidant capacity of leaves of Tephrosia purpurea Linn. (Leguminosae) Int J Pharma Sci Res 2010;1;66-77.

15. Jain UK, Dixit VK. Spectrophotometric estimation of tannins from chyavanprash. Indian Drugs 2004;41:469-72.

16. Chu YH, Chang CL, Hsu HF. Flavonoid contents of various vegetables and their antioxidant activity. J Sci Food Agric 2000;80:561-6.

17. Barku VYA, Opoku-Boahen Y, Owusu-Ansah E, Mensah EF. Antioxidant activity and the estimation of total phenolic and flavonoid contents of the root extract of Amaranthus spinosus. Asian J Plant Sci Res 2013;3:69-74.
18. Oyaizu M. Studies on products of browning reactions: antioxidative activities of products of browning reaction prepared from glucosamine. Jpn J Nutr 1986;103:413-9.

19. Gupta N, Agarwal M, Bhatia V, Jha SK, Dinesh J. In vitro antioxidant activity of crude extracts of the plant Glycosmis pentaphylla Correa. Int J Pharm Sci Rev Res 2011;6:29.

20. Harman D. Aging: phenomena and theories. Ann NY Acad Sci 1998;854:1-7.

21. Liu GT. Pharmacological actions and clinical use of Fructus schizandrae. Chin Med J 1989;102:740-9.

22. Hayes F, Kato H. Antioxidative components of sweet potatoes. J Nutr Sci Vitaminol 1984;30:37-46.

23. Zheng W, Wang SY. Antioxidant activity and phenolic compound in selected herbs. J Agric Food Chem 2001;49:5165-70.

24. Anandjiwala S, Bagul MS, Parabia M, Rajani M. Evaluation of free radical scavenging activity of an ayurvedic formulationPanchvalkala. Indian J Pharm Sci 2008;70:31-6.

25. Fawole OA, NP Makunga UL. Opara antibacterial, antioxidant and tyrosinase inhibition activities of pomegranate fruit peel methanolic extract. BMC Complementary Altern Med 2012;200 Suppl 12:2-11.

26. Heim KE, Tagliaferro AR, dan Bobilya DJ. Flavonoid antioxidants: chemistry, metabolism, and structure-activity relationships. J Nutr Biochem 2002;13:572-84

27. Sri J, Yu J, Pohorly J, Young C, Bragan M, Wu J. Optimization of the extraction of polyphenolics from grapes seed and aqueous ethanol solution. Food Agric Environ 2006;1:42-7.

28. Aiyegoro AO, Okoh AI. Preliminary phytochemical screening and in vitro antioxidant activities of the aqueous extract of Helichrysum lungi folium DC. BMC Complementary Altern Med 2010;10:21.

\section{How to cite this article}

- B Usha, KC Pushpalatha. In vitro antioxidant activity and phytochemical screening of leaf extracts of grewia heterotricha mast. Int J Curr Pharm Res 2016;8(4):68-72. 